\title{
FGF3 Gene
}

National Cancer Institute

\section{Source}

National Cancer Institute. FGF3 Gene. NCI Thesaurus. Code C18408.

This gene plays a role in the regulation of cell growth. 